\title{
Pharmacoepidemiological study of self-medication in adults attending pharmacies in Alexandria, Egypt
}

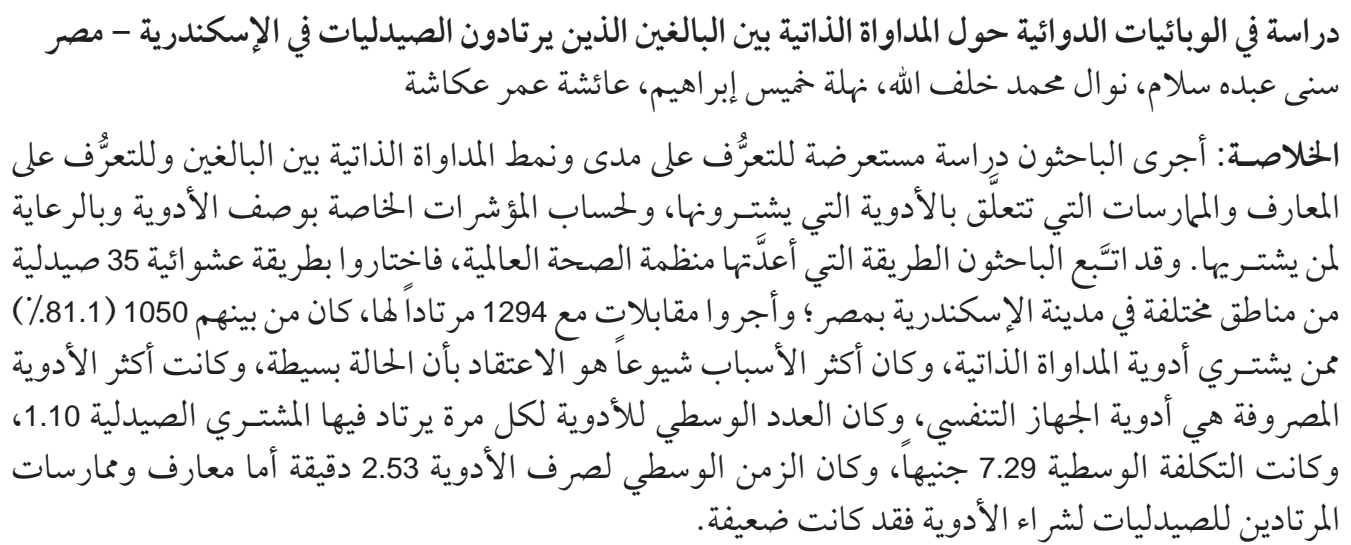

ABSTRACT A cross-sectional study was conducted to determine the extent and pattern of selfmedication among adults, to identify their knowledge and practice concerning the purchased drugs and to calculate prescribing and purchaser care indicators. Following WHO methods, 35 pharmacies were randomly selected from districts in Alexandria city, Egypt. Of 1294 clients interviewed at these pharmacies, 1050 (81.1\%) purchased self-medication; the commonest reason given was a belief that the condition was minor. The most frequently dispensed drugs were those for the respiratory system. The mean number of drugs per encounter was 1.10, mean cost LE 7.29 and mean dispensing time 2.53 minutes. Purchasers' knowledge and practice regarding the purchased drugs were poor.

\begin{abstract}
Étude pharmacoépidémiologique de l'automédication chez les adultes s'approvisionnant dans des pharmacies d'Alexandrie (Égypte)

RÉSUMÉ Une étude transversale a été menée pour déterminer l'étendue et les caractéristiques de l'automédication chez les adultes, recenser les connaissances et les pratiques de ces personnes concernant les médicaments achetés, et calculer les indicateurs de prescription ainsi que les indicateurs de soins relatifs aux acheteurs. Conformément aux méthodes de l'OMS, 35 pharmacies ont été sélectionnées au hasard dans différents quartiers d'Alexandrie (Égypte). Sur 1294 clients interrogés dans ces pharmacies, $1050(81,1 \%)$ achetaient des médicaments pour se soigner euxmêmes ; parmi les raisons avancées, la principale était que d'après eux, ils ne souffraient pas d'une affection grave. Les médicaments les plus fréquemment délivrés étaient ceux destinés à l'appareil respiratoire. Le nombre moyen de médicaments par déplacement à la pharmacie était de 1,10; le coût moyen, de 7,29 livres égyptiennes; et la durée moyenne de délivrance, de 2,53 minutes. Le niveau de connaissances et de pratiques des clients à propos des médicaments achetés était faible.
\end{abstract}

${ }^{1}$ High Institute of Public Health; ${ }^{2}$ Faculty of Pharmacy, University of Alexandria, Alexandria, Egypt (Correspondence to A.O.Okasha: aisha@doctor.com).

Received: 11/07/06; accepted: 18/10/06 


\section{Introduction}

Pharmacoepidemiology is considered newly evolving science that studies the use and effects of drugs in large numbers of people [1]. Rational use of drugs has drawn public health attention globally with the aim of maintaining quality health care at lower cost [2]. As dispensing medication in an appropriate way is a cornerstone of rational drug use, the dispenser should be regularly updated with information, tools and skills [3].

Self-medication has been defined as self-administration of medication not prescribed by, or in a manner not directed by, a physician [4]. The public health importance of self-medication has increased since the late 1980s when more drugs were changed from prescription status to be sold over-thecounter (OTC) without a prescription. This is a worldwide trend. The increased possibilities of self-medication have implications for patients, pharmacists, and physicians [5]. It also allows pharmaceutical companies to expand their market [6].

Self-medication is common among individuals in many developing countries but not much is known about its determinants [7], and increasingly self-prescribed medications are obtained and consumed without the advice of the physician [8]. In Egypt in 1996 it was reported that some drugs that were unavailable in many developed countries because of the risks of adverse effects were still manufactured, marketed, prescribed by physicians, recommended by pharmacists and requested for purchase by clients [9]. It is customary in Egypt for drug products to be sold OTC without any prescription, except for a very limited number of drugs specified by the Ministry of Health and Population that require a special prescription for dispensing.

A limited number of drug utilization studies have been conducted in Egypt [10].
A pharmacoepidemiological study on drug utilization among children in Alexandria in 1995 reported that $21.1 \%$ of purchased medications were not prescribed [11]. Another study among university students showed that $66.1 \%$ took medicines without prescription [12]. The aim of this study was to determine the pattern of self-medication among adults attending pharmacies in Alexandria, to identify their knowledge and self-reported practices concerning the usage of the purchased drugs and to calculate the prescribing and purchaser care indicators for the encounters.

\section{Methods}

The study design and sample size followed World Health Organization (WHO) guidelines for investigation of therapeutic practice [13]. Accordingly, a sample of 35 pharmacies was selected randomly from all 7 districts of Alexandria, using the proportional allocation technique, where 30 encounters were included from each selected pharmacy. In order to reach the required sample size, all adults aged 20-64 years attending the selected pharmacies requesting drugs (with or without prescription) were selected. Among all adult clients requesting self-medication drugs (a product for selfuse without a prescription indicated for the current complaint), a total sample of 1050 purchasers were interviewed.

Data collection was done through a questionnaire interview of purchasers and observation of the encounter. The interview questionnaire contained items about the purchaser: demographic characteristics (age, sex, education and occupation); complaint; duration of condition; source of advice and reason for self-medication; knowledge about the use of the purchased drug; and practices related to the product purchased. The observation sheet included items about

المجلة الصحية لشرق المتوسط، منظمة الصحة العالمية، المجلد الخنامس عشر، العدد ب، 9 +. 
the dispensing procedure: history-taking; case referral; labelling of drugs; oral instructions about use; and whether the purchasers asked for any advice from the dispenser.

The dispensing time was recorded for each encounter. Data about the purchased drug was also recorded, such as trade name, generic name, dosage form and cost. Certain prescribing and purchaser care indicators were calculated according to WHO guidelines [13].

Analysis of data was conducted using SPSS, version 9.

\section{Results}

The sample of adults attending the pharmacies (with or without prescription) was 1294. A total of $1050(81.1 \%)$ purchased products for self-medication and were included in the study.

The demographic characteristics of the purchasers of self-medication revealed a slight male predominance $(56.5 \%)$; about two-thirds were married (61.7\%). The mean age was 39.2 years; $27.9 \%$ were aged $20-29$ years. Regarding educational level, $52.5 \%$ of purchasers were university graduates, while $16.6 \%$ and $19.8 \%$ respectively were illiterate or could just read and write. The most common occupation was housewife $(23.0 \%)$, followed by clerical worker $(16.2 \%)$.

The most frequent complaints expressed by purchasers of self-medication were common cold $(9.2 \%)$, headache $(7.4 \%)$, hypertension (5.6\%), cough $(5.0 \%)$ and dyspepsia (4.7\%). Table 1 shows the complaints categorized by system; the most frequent were those of the respiratory system $(21.0 \%)$, followed by the alimentary system (15.8\%). Neurological and mental health problems represented $12.9 \%$, followed by skin problems and cardiovascular problems, with $9.5 \%$ and $8.9 \%$ respectively.

\begin{tabular}{lrr}
\hline \multicolumn{3}{l}{$\begin{array}{l}\text { Table } 1 \text { Distribution of adult purchasers of } \\
\text { self-medication at Alexandria pharmacies by } \\
\text { self-reported category of complaint }\end{array}$} \\
\hline \multicolumn{1}{l}{ Category of complaint } & No. & \multicolumn{1}{c}{$\%$} \\
\hline Respiratory problem & 221 & 21.0 \\
Alimentary problem & 166 & 15.8 \\
Neurological/mental health & & \\
$\quad$ problem & 135 & 12.9 \\
Skin problem & 100 & 9.5 \\
Cardiovascular problem & 93 & 8.9 \\
Pain & 82 & 7.8 \\
Fatigue & 47 & 4.5 \\
Diabetes & 37 & 3.5 \\
Sensory organ problem & 31 & 3.0 \\
Gynaecological problem & 29 & 2.8 \\
Genitourinary problem & 20 & 1.9 \\
Dental problem & 19 & 1.8 \\
Other & 70 & 6.7 \\
Total & 1050 & 100.0 \\
\hline
\end{tabular}

Data concerning the present complaint revealed that about half of purchasers (48.5\%) had had the complaint for less than 1 week; while one-third had had the condition for more than 6 months (32.8\%) (Table $2)$. The majority $(88.5 \%)$ had previously complained of the same condition. Previous use of the same product purchased was reported by $77.2 \%$.

About half of the purchasers attributed the reason for self-medication to a perception of their problem as minor (44.5\%), followed by $31.0 \%$ claiming to know the treatment from a previous prescription (Table 3).

Source of advice was mainly a prescription not issued for the current complaint $(33.0 \%)$, the purchaser's own initiative $(25.3 \%)$ and the pharmacist $(22.0 \%)$ (Table $4)$.

Table 5 shows knowledge and selfreported practices of self-medication purchasers concerning the drug purchased. Drug-related knowledge among adults was poor: $88.3 \%, 92.9 \%, 95.7 \%$ and $95.4 \%$ of

المجلة الصحية لشرق المتوسط، منظمة الصحة العالمية، المجلد الخنامس عشر، العدد ب، 9 +. 


\begin{tabular}{|c|c|c|}
\hline Factor related to complaint & No. & $\%$ \\
\hline$<1$ week & 509 & 48.5 \\
\hline 1 to $\leq 4$ weeks & 116 & 11.0 \\
\hline $1-6$ months & 81 & 7.7 \\
\hline$>6$ months & 344 & 32.8 \\
\hline \multicolumn{3}{|l|}{$\begin{array}{l}\text { Previous complaint of same } \\
\text { condition }\end{array}$} \\
\hline Yes & 929 & 88.5 \\
\hline No & 121 & 11.5 \\
\hline \multicolumn{3}{|l|}{$\begin{array}{l}\text { Previous use of same } \\
\text { medication and completion of } \\
\text { course }\end{array}$} \\
\hline Used and completed course & 594 & 56.6 \\
\hline Used but incomplete course & 217 & 20.6 \\
\hline No previous use & 239 & 22.8 \\
\hline
\end{tabular}

purchasers did not know the drug dose, side-effects, precautions and contraindications of the purchased drugs respectively. Regarding self-reported practices, only $50.6 \%$ had read the patient information sheet, $62.2 \%$ had read the expiry date and $50.3 \%$ had followed the pharmacist's instructions on the label.

Statistically significant differences were found between the educational level of purchasers and behaviour concerning the purchased drugs (Table 6); purchasers with a higher level of education were more likely to read the patient information sheet, follow the pharmacist's label and read the expiry date of drug purchased; $P<0.001$ for all behaviours.

Regarding the purchasers' practices when ill, $79.9 \%$ reported taking self-medication as their first action, $96.0 \%$ said that they turned to self-medication for perceived minor problems only and three-quarters perceived self-medication to be always effective in treating their condition. About

\begin{tabular}{lrr}
\hline \multicolumn{3}{l}{$\begin{array}{l}\text { Table } 3 \text { Distribution of self-medication } \\
\text { purchasers }(\boldsymbol{n}=1050) \text { at Alexandria }\end{array}$} \\
\begin{tabular}{l} 
pharmacies by reason for self-medication \\
\hline $\begin{array}{l}\text { Reason for self-medication } \\
\text { Rear }\end{array}$
\end{tabular} \\
\hline $\begin{array}{l}\text { Perceived problem as minor not } \\
\quad \text { requiring medical attention }\end{array}$ & 467 & 44.5 \\
$\begin{array}{l}\text { Know the treatment from } \\
\quad \text { previous prescription }\end{array}$ & 325 & 31.0 \\
Confidence in the pharmacist & 152 & 14.5 \\
Cannot afford to see the doctor & 52 & 4.9 \\
No time to see the doctor & 32 & 3.0 \\
No confidence in the doctor & 22 & 2.1 \\
\hline
\end{tabular}

half of purchasers could not remember when they had last visited the doctor. Nonpharmacological home remedies were used by $61.3 \%$.

Concerning the type of drug products regularly available at home, more than half of them were anti-inflammatory and analgesic drugs (58.5\%), followed by cough $(11.5 \%)$ and common cold $(7.3 \%)$ remedies. The most frequent groups of drugs purchased were products for alimentary tract and metabolic disorders (30.4\%), followed by those for respiratory system disorders $(16.1 \%)$ (Table 7$)$. The most frequent generic names requested were chlorpheniramine $(7.7 \%)$, followed by diclofenac $(4.5 \%)$. More than one-half of the drug products purchased $(69.9 \%)$ were in oral solid dosage form (89.6\% tablets and $10.4 \%$ capsules). Banned products such as dipyrone were requested by the purchasers.

Observed dispensing procedure showed that $17.5 \%$ of purchasers had a case history taken and $6.2 \%$ were referred for medical care. The pharmacist was asked for advice by $29.6 \%$ of purchasers (Table 8 ).

Regarding the prescribing indicators, the mean number of drugs per encounter was 1.10 , the mean drug cost per encounter was Egyptian pounds (LE) 7.29, and the percentage of encounters with 1 or more antibiotic dispensed was $6.8 \%$. 


\begin{tabular}{|c|c|c|}
\hline $\begin{array}{l}\text { Source of advice for self- } \\
\text { medication }\end{array}$ & No. & $\%$ \\
\hline Purchaser's own initiative & 266 & 25.3 \\
\hline Prescription not issued for the & & \\
\hline current complaint & 346 & 33.0 \\
\hline Personal prescription & (325) & $(30.9)$ \\
\hline Prescription issued to others & $(21)$ & (2.1) \\
\hline Pharmacist & 231 & 22.0 \\
\hline Pharmacist assistant & 20 & 1.9 \\
\hline Lay people & 187 & 17.8 \\
\hline
\end{tabular}

As regards purchaser care indicators, the mean dispensing time was 2.53 minutes, the percentage of drugs adequately labelled was $17.4 \%$, the percentage of drugs dispensed with oral instructions was $28.2 \%$ and the percentage of drugs actually dispensed was $100 \%$.

\section{Discussion}

In the present study the rate of selfmedication was high $(81.1 \%)$, due partly to the lack of enforcement of the Egyptian law concerning drug products requiring a prescription to be sold OTC. Moreover, self-medication appears to be increasing compared to the pattern of drug supply from pharmacies in Alexandria in 1996 which showed that $72 \%$ of drugs in all therapeutic categories were dispensed without a prescription or advice from a pharmacist [9]. The findings of a study in south Brazil were consistent with the latter, where $76.1 \%$ of medicine users were self-medicated [14].

The educational level of the adult purchasers in the present study indicated that university graduates constituted $52.5 \%$. Probably this educated group feels it has more ability to self-medicate. In India, Deshpande and Tiwari reported that

\begin{tabular}{|c|c|c|}
\hline \multicolumn{3}{|c|}{$\begin{array}{l}\text { Table } 5 \text { Distribution of self-medication } \\
\text { purchasers }(n=1050) \text { at Alexandria } \\
\text { pharmacies by knowledge and practice } \\
\text { about the drug purchased }\end{array}$} \\
\hline $\begin{array}{l}\text { Knowledge/practice about } \\
\text { drug purchased }\end{array}$ & No. & $\%$ \\
\hline \multicolumn{3}{|l|}{ Knowledge of: } \\
\hline \multicolumn{3}{|l|}{ Dose } \\
\hline Yes & 123 & 11.7 \\
\hline No & 927 & 88.3 \\
\hline \multicolumn{3}{|l|}{ Side-effects } \\
\hline Yes & 15 & 1.4 \\
\hline No & 975 & 92.9 \\
\hline Will read in information sheet & 60 & 5.7 \\
\hline \multicolumn{3}{|l|}{ Precautions } \\
\hline Yes & 5 & 0.5 \\
\hline No & 1005 & 95.7 \\
\hline Will read in information sheet & 40 & 3.8 \\
\hline \multicolumn{3}{|l|}{ Contraindications } \\
\hline Yes & 8 & 0.8 \\
\hline No & 1002 & 95.4 \\
\hline Will read in information sheet & 40 & 3.8 \\
\hline \multicolumn{3}{|l|}{ Practice: } \\
\hline Expected duration of use & 40 & 3.8 \\
\hline Until complaint disappears & 728 & 69.3 \\
\hline Until drug finishes & 297 & 28.3 \\
\hline Adjusted by adviser & 25 & 2.4 \\
\hline \multicolumn{3}{|l|}{$\begin{array}{l}\text { Read patient information } \\
\text { sheet }\end{array}$} \\
\hline Yes & 531 & 50.6 \\
\hline No & 519 & 49.4 \\
\hline \multicolumn{3}{|l|}{$\begin{array}{l}\text { Reasons for not reading } \\
\text { information sheet }\end{array}$} \\
\hline Difficult to read & 177 & 34.0 \\
\hline Confidence in pharmacist & 44 & 8.5 \\
\hline Difficult to understand & 243 & 46.8 \\
\hline Written in English & 18 & 3.5 \\
\hline No need to read it & 37 & 7.2 \\
\hline \multicolumn{3}{|l|}{$\begin{array}{l}\text { Followed pharmacist's label } \\
\text { instructions }\end{array}$} \\
\hline Yes & 528 & 50.3 \\
\hline No & 522 & 49.7 \\
\hline \multicolumn{3}{|l|}{ Read expiry date } \\
\hline Yes & 653 & 62.2 \\
\hline No & 397 & 37.8 \\
\hline
\end{tabular}




\begin{tabular}{|c|c|c|c|c|c|c|}
\hline \multirow[t]{2}{*}{$\begin{array}{l}\text { Purchasers' education } \\
\text { level }\end{array}$} & \multicolumn{2}{|c|}{$\begin{array}{c}\text { Read patient } \\
\text { information sheet }\end{array}$} & \multicolumn{2}{|c|}{$\begin{array}{c}\text { Followed } \\
\text { pharmacist's label }\end{array}$} & \multicolumn{2}{|c|}{$\begin{array}{l}\text { Read drug } \\
\text { expiry date }\end{array}$} \\
\hline & No. & $\%$ & No. & $\%$ & No. & $\%$ \\
\hline Illiterate $(n=174)$ & 11 & 6.3 & 23 & 13.2 & 33 & 19.0 \\
\hline $\begin{array}{l}\text { Read and write/primary } \\
\text { school }(n=212)\end{array}$ & 40 & 18.9 & 73 & 34.4 & 100 & 47.2 \\
\hline $\begin{array}{l}\text { Preparatory/secondary } \\
\text { school }(n=113)\end{array}$ & 42 & 37.2 & 45 & 39.8 & 70 & 61.9 \\
\hline $\begin{array}{l}\text { University graduate } \\
\quad(n=551)\end{array}$ & 438 & 79.5 & 387 & 70.2 & 450 & 81.7 \\
\hline Total $(n=1050)$ & 531 & 50.6 & 528 & 50.3 & 653 & 62.2 \\
\hline Significance & \multicolumn{2}{|c|}{$\chi^{2}=414.0 ; P<0.001$} & \multicolumn{2}{|c|}{$\chi^{2}=209.6 ; P<0.001$} & \multicolumn{2}{|c|}{$\chi^{2}=247.5 ; P<0.001$} \\
\hline
\end{tabular}

$26 \%$ of graduates and $23.1 \%$ of illiterate people practised self-medication [15]. Another study in India in an urban slum community indicated that the practice of selfmedication was more prevalent among literate people [16]. Among primary care patients in a clinic in Riyadh, literate patients also tended to self-medicate more than illiterate ones [17]. In Sri Lanka, it was suggested that literate people self-medicated far more than illiterate people [18]. In the present study $83.3 \%$ of self-prescribers were literate and $16.6 \%$ illiterate.

Pharmacists $(22.0 \%)$ and to a less extent pharmacist assistants $(1.9 \%)$ were a source of advice to purchasers in the present study. Pharmacists diagnosed certain conditions and prescribed a drug as a treatment. A quarter of the purchasers sought medication on their own initiative. A study on family use and understanding of modern medicine in 2 villages in rural Brazil indicated that the majority of medications were prescribed by pharmacist assistants or by the patients themselves [19]. Deshpande and Tiwari's study in India found that $30.8 \%$ purchased a particular medicine on advice from friends or neighbours [15].

The commonest reason given for selfmedication was purchasers' belief that their complaint was a minor problem, not requiring medical attention (44.5\%). About one-third of the purchasers claimed that they knew the treatment from a previous prescription $(31 \%)$, while $14.5 \%$ had confidence in the pharmacist. The study in Riyadh indicated that $58 \%$ of purchasers attempted self-medication due to the triviality of their symptoms or to save time and money [17]. In the slum community in India inability to pay for established medical facilities was the commonest motivation for self-medication (60.5\%) [16].

Purchasers' knowledge relating to the purchased drug product was poor, although $77.2 \%$ had previously used the same product. A study in Alexandria investigating 4 different drug groups purchased without a prescription reported that $74 \%$ of the clients had used the product before [20]. The majority of the purchasers did not know the dose intended to be taken $(88.3 \%)$, sideeffects $(92.9 \%)$, precautions $(95.7 \%)$ and contraindications $(95.4 \%)$. Other studies have identified clients' lack of information about drug products. Comparing the quality of service in pharmacies in Yugoslavia, patients' knowledge of the correct dosage ranged from $30 \%$ to $74 \%$ [21]. Research has demonstrated that individuals have 
Table 7 Distribution of drugs purchased for self-medication at Alexandria pharmacies by drug group

\begin{tabular}{lrr}
\hline Drug group & No. & \multicolumn{1}{c}{$\%$} \\
\hline Alimentary and metabolic & 351 & 30.4 \\
$\quad$ system & 186 & 16.1 \\
Respiratory system & 127 & 11.0 \\
Musculoskeletal & 114 & 9.9 \\
Central nervous system & 113 & 9.8 \\
Cardiovascular system & 73 & 6.3 \\
Dermatological & 72 & 6.2 \\
Anti-infective, systemic & 40 & 3.5 \\
Genitourinary system & 34 & 2.9 \\
Sensory organ & 23 & 2.0 \\
Blood disorder & 12 & 1.0 \\
Antiparasitic & 7 & 0.6 \\
Systemic hormonal & & \\
Antineoplastic and & 1 & 0.1 \\
$\quad$ immunological system & 1153 & 100.0 \\
\hline Total & & \\
\hline
\end{tabular}

their own ideas and beliefs about drug use, which are important determinants of their use [22-24].

Investigating self-medication and drugtaking behaviour revealed that most of the purchasers generally sought to selfmedicate for minor problems $(96 \%)$ while those who self-medicate for major problems were a minority $(0.3 \%)$. A survey in Malaysia indicated a marked tendency among the general population to treat minor ailments by self-medication with OTC drugs [25].

Our findings about self-reported practices concerning purchased drugs suggest that purchasers make their own judgements and adjustments regarding adherence to medication regimens. Education appeared to be an important variable as the higher the purchasers' educational level, the more they complied with reading the patient information sheet, following the label instructions and reading the expiry date. In a community study in Spain, the instructions were read in only $48.6 \%$ of cases [26].

\begin{tabular}{|c|c|c|}
\hline \multicolumn{3}{|c|}{$\begin{array}{l}\text { Table } 8 \text { Distribution of self-medication } \\
\text { purchasers }(n=1050) \text { at Alexandria } \\
\text { pharmacies by dispensing procedure } \\
\text { observed }\end{array}$} \\
\hline Observed procedure & No. & $\%$ \\
\hline \multicolumn{3}{|l|}{ Patient asked advice } \\
\hline Yes & 311 & 29.6 \\
\hline No & 739 & 70.4 \\
\hline \multicolumn{3}{|c|}{ Case history taken from patient } \\
\hline Yes & 184 & 17.5 \\
\hline No & 866 & 82.5 \\
\hline \multicolumn{3}{|l|}{ Drug labelled } \\
\hline Yes & 183 & 17.4 \\
\hline No & 867 & 82.6 \\
\hline \multicolumn{3}{|l|}{ Oral instructions given } \\
\hline Yes & 296 & 28.2 \\
\hline No & 754 & 71.8 \\
\hline \multicolumn{3}{|l|}{ Medical referral made } \\
\hline Yes & 65 & 6.2 \\
\hline No & 985 & 93.8 \\
\hline
\end{tabular}

In the present study, the most frequent complaints were common cold $(9.2 \%)$ and headache $(7.4 \%)$. A survey of selfmedication in eastern France stated that the 3 most frequent symptoms were headache $(46.9 \%)$, nose, throat or respiratory tract diseases $(22.1 \%)$ and abdominal pain (7.3\%) [27]. Deshpande and Tiwari's study in India showed that cough (22.2\%), fever $(17.4 \%)$, boils $(7.6 \%)$ and stomach acidity $(6.8 \%)$ were the common complaints for self-prescription [16]. A telephone survey among 660 homes in Spain reported headache $(42.8 \%)$, lumbago $(41.7 \%)$ and colds (34.4\%) as the most frequent symptoms. Self-medication, including physical and home remedies, was the most common response [28]. Products such as dipyrone were requested by some purchasers. In many parts of the world dipyrone is considered a dangerous drug and is no longer used, as fatalities were observed more than 60 years ago [29]. However, it continues to be marketed in some countries [30]. 
The mean number of drugs dispensed per encounter was 1.10 and the percentage of drugs actually dispensed was $100 \%$. In the study in Yugoslavia the percentage of drugs actually dispensed was $29 \%$ to $63 \%$ [21]. A study on rational drug use in Ethiopia showed that most drugs in health centres $(89 \%)$ and in health stations $(71 \%)$ were actually dispensed, while the mean number of drugs per encounter was $<2.5[31]$.

In the present study the mean cost of drugs per encounter was LE 7.29. A survey in 1995 in 3 outpatient facilities among 331 encounters in Ismailia governorate in Egypt reported that the mean drug cost was LE 8.40 and the percentage drugs actually dispensed was $54.0 \%$ [32].
In some drug utilization studies, such as this one, the parameters assessed were subjective, which is a limitation of such studies.

\section{Conclusion}

Several aspects of irrational drug use were found in this study, with a very high rate of self-medication and poor knowledge and practice concerning the purchased drugs. It is recommended that the dispensing procedure in Egypt needs improvement through educational, regulatory and managerial strategies.

\section{References}

1. Etminan $\mathrm{M}$ et al. Challenges and opportunities for pharmacoepidemiology in drug-therapy decision making. Journal of clinical pharmacology, 2006, 46(1):6-9.

2. Bazaldua $O$ et al. Suggested guidelines for pharmacotherapy curricula in family medicine residency training: recommendations from the Society of Teachers of Family Medicine Group on Pharmacotherapy. Family medicine, 2005, 37(2):99-104.

3. Vacca $\mathrm{C}$ et al. Assessment of risks related to medicine dispensing by nonprofessionals in Colombia: clinical case simulations. Annals of pharmacotherapy, 2005, 39(3):527-32.

4. Guarlink DB, ed. Webster's new world dictionary. New Delhi, Bombay, Oxford, MBH Publishing Co, 1998.

5. Cranz H. Health economics and self medication. Journal of social and administrative pharmacy, 1990, 7:184-9.

6. Francis SA, Barnett N, Denham M. Switching of prescription drugs to overthe-counter status: is it a good thing for the elderly? Drugs and aging, 2005 22(5):361-70.

7. Pagan JA et al. Self-medication and health insurance coverage in Mexico. Health policy, 2006, 75(2):170-7.

8. Chang FR, Trivedi PK. Economics of selfmedication: theory and evidence. Health economics, 2003, 12(9):721-39.

9. Benjamin H, Smith F, Motawi A. Drugs dispensed with and without a prescription from community pharmacies in a conurbation in Egypt. Eastern Mediterranean health journal, 1996, 2:506-14.

10. The world health report 1998. Life in the 21st century: vision for all. Geneva, World Health Organization, 1998.

11. Ibrahim NK. Drug utilization in respiratory and diarrheal diseases among children: an epidemiologic study [MPH thesis]. Alexandria, High Institute for Public Health, University of Alexandria, 1995.

12. Fadel KA, Qayed MH. Self medication and care among university students, As- 
siut, Egypt 1996. Bulletin of the High Institute of Public Health, 1997, 27(1).

13. How to investigate drug use in health facilities. Selected drug use indicators. Action program on essential drugs. Geneva, World Health Organization, 1993 (WHO/ DAP/93.1).

14. Vilarino JF et al. Perfil da automedicação em municipio do Sul do Brasil [Self medication profile in a city of South Brazil]. Revista de saúde pública, 1998, 32(1):43-9.

15. Deshpande SG, Tiwari R. Self medication: a growing concern. Indian journal of medical science, 1997, 51(3):93-6.

16. Durgawale PM. Practice of self medication among slum-dwellers. Indian journal of public health, 1998, 42(2):53-5.

17. Saeed AA. Self medication among primary care patients in Farazdak clinic in Riyadh. Social science and medicine, 1998, 27(3):287-9.

18. Abosede OA. Self medication: an important aspect of primary health care. Social science and medicine, 1984, 19(7):699703.

19. Haak H. Pharmaceuticals in two Brazilian villages: lay practices and perception. Social science and medicine, 1988, 27(12):1415-27.

20. Benjamin H, Smith F, Motawi A. Nonprescription products purchased from pharmacies in Alexandria. Journal of social and administrative pharmacy, 1998, 15(1):50-6.

21. Janković SM et al. Service quality in public and private pharmacies in the city of Kragujevac, fr Yugoslavia. Croatian medical journal, 2001, 42(1):88-91.

22. Michel JM. Why do people like medicines? A perspective from Africa. Lancet, 1985, 1(8422):210-11.

23. Van der Geast S, Hardon A. Self medication in developing countries. Journal of social administrative pharmacy, 1990, 7(4):199-204.

24. Davis $\mathrm{P}$, ed. For health or profit? Medicine, the pharmaceutical industry and the state in New Zealand. Auckland, Oxford University Press, 1992.

25. Ibrahim Ml. Treating one's own ailments. World health forum, 1996, 17(4):409-10.

26. Tejdor $\mathrm{N}$ et al. Trastornos comunes de salud: autocuidado y automedicacion [Common health disorders: self-care and self-medication]. Atencion primaria, 1995 , 16(1):13-8.

27. Laure P. Enquête sur les usagers de l'automédication: de la maladie à la performance [Investigation on self medication: from disease to performance]. Therapie, 1998, 53(2):127-35.

28. Nebot M, Llauger MA. Autocuidado de los trastornos comunes de salud: resultados de una encuesta telefónica en la población general [Self care of common health disorders: results of a telephone survey of the general population]. Medicina clinica, 1992, 99(11):420-4.

29. Simpson RG. Aminopyrine and agranulocytosis. British medical journal, 1963, 1(5334):887

30. Hugueley CM. Agranulocytosis induced by dipyrone, a hazardous antipyretic and analgesic. Journal of the American Medical Association, 1964, 189(12):938-41.

31. Desta $Z$ et al. Assessment of rational drug use and prescribing in primary health care facilities in North West Ethiopia. East African medical journal, 1997, 74(12):75863.

32. Khedr MS. Evaluation of rational drug prescribing in out patient facilities in Ismailia, Egypt. Paper presented at the IEA Eastern Mediterranean Regional Meeting, Alexandria, Egypt, 1-4 September, 1995. 